Abstracts / Résumés 


\section{Pierre Anctil}

«Créée par le peuple et pour le peuple » : Réflexions sur les origines historiques de la Bibliothèque publique juive de Montréal

La Bibliothèque publique juive de Montréal a été fondée grâce aux pressions conjuguées de deux grands courants d'idées présents dans la ville depuis le début de la grande vague migratoire est-européenne. D'une part l'institution était redevable aux conceptions modernistes et universalistes de la haskala, incarnées entre autres à Montréal par le penseur Reuben Brainin; et de l'autre elle avait bénéficié des exceptionnelles capacités organisationnelles d'un parti sioniste de gauche né de l'insurrection russe de 1905 , le Poale-Zion. C'est la conjoncture historique que l'auteur met en valeur dans son article, notamment en parcourant le premier rapport annuel de la BPJ publié en 1915 et qui présente de nombreux témoignages en ce sens.

The Montreal Jewish Public Library (JPL) was founded in the wake of two broad ideological movements that had permeated the city since the beginning of the large Eastern-European migration. On the one hand, the institution was influenced by modernist and universalist concepts found in the Haskalah, promoted among others by Montreal thinker Reuben Brainin; and on the other, it benefited form the exceptional organizational strength of a left-wing Zionist party born out of the 1905 Russian Revolution, Poale-Zion. The author highlights this historical conjuncture, by exploring the first annual report of the JPL published in 1915, which bears numerous testimonies to that effect.

\section{Zackary Baker}

\section{A Goodly Tent of Jacob, and the Canadian Home Beautiful}

Four ceremonial events from the history of the Jewish Public Library are discussed in this article. They concerned the erection of the new building at 4499 Esplanade (195I-1953) and the inauguration of the Bronfman Collection of Jewish Canadiana (I954). The ceremonies reveal the Library in formal interaction with different spheres of the Jewish community and the Canadian body politic. They were taped and can be heard over the Internet. These recordings serve as an auditory lieu de mémoire for an institution that embodies both a place and an ideal.

L'article traite de quatre événements cérémoniels de l'histoire de la Bibliothèque publique juive de Montréal lors de la construction du nouvel édifice au 4499, rue de l'Esplanade (I95I-1953) et l'inauguration de la collection Bronfman de canadiana judaïque (1954). Les cérémonies révèlent une Bibliothèque en interaction formelle avec différentes sphères de la communauté juive et des politiciens canadiens. Les échanges ont été enregistrés et sont disponibles sur Internet. Les enregistrements servent de lieu de mémoire auditif pour une institution qui se veut à la fois un lieu et un idéal. 


\section{Ira Robinson}

\section{Ninety-Nine Meetings: The Jewish Public Library of Montreal in its First Century}

As the Jewish Public Library (JPL) of Montreal celebrates its centennial, I was asked to contribute a general evaluation of its first century. My approach was to examine the ninety-nine reports presented annually to JPL members at the Library's Annual Meetings (AM). These reports come in different styles and languages, however they all attempt to present a fair summary of the JPL's position and activities in the year under review and hence, taken collectively, they represent, in my opinion, the best means to begin to understand JPL in its first century. What follows constitutes my reflections on JPL's first ninety-nine AMs.

Pour le centenaire de la Bibliothèque publique juive (BPJ) de Montréal, on m'a demandé de procéder à une évaluation générale de son premier siècle d'histoire. Mon approche a consisté en un examen des quatre-vingt-dix-neuf rapports annuels présentés aux membres de la BPJ lors de l'assemblée générale annuelle. Ces rapports sont rédigés selon différents styles et en différentes langues. Ils tentent tous cependant de présenter un résumé juste de la position et des activités de la BPJ pour l'année de référence et ainsi, pris dans leur ensemble, ils représentent, à mon avis, le meilleur moyen de commencer à comprendre le premier siècle de l'histoire de la BPJ. L'article présente mes réflexions sur les quatre-vingt-dix-neuf premières assemblées générales annuelles.

\section{Eva Roskies Raby}

\section{The Norman Berman Children's Library, 1983-2013}

The Norman Berman Children's Library (NBCL) of the Jewish Public Library is focused on engaging the Jewish community of Montreal from its youngest members on. In I982 a special task force was created by the Board of the Jewish Public Library to examine how best to expand the Children's Library services, collections and its physical premises. The article focuses on the implementation of its report. It describes the many incarnations of the Library's physical space to accommodate the changing and growing needs of collections, services and staff. It demonstrates how collections have evolved to reflect the changes of Jewish life through the decades and how its innovative and diverse programming has engaged and impacted the cultural life of multiple communities, Jewish and non-Jewish.

La Bibliothèque pour enfants Norman Berman (BENB) de la Bibliothèque publique juive (BPJ) a pour mission de rejoindre la communauté juive de Montréal et plus particulièrement les plus jeunes. En 1982, un groupe de travail ad hoc a été mis sur pied par le conseil d'administration de la BPJ pour examiner comment mieux rehausser les services, les collections et les installations de la Bibliothèque pour enfants. 
L'article porte sur la mise en œuvre du rapport. Sont décrites les différentes incarnations de l'espace physique qu'a occupé la Bibliothèque pour répondre aux besoins changeants et croissants des collections, des services et des employés. On y démontre l'évolution des collections qui reflète les changements à la vie juive au cours des décennies et comment une programmation novatrice et diversifiée a permis de mieux rejoindre les communautés juives et non juives et de rehausser leur vie culturelle.

\section{Stephanie Tara Schwartz}

\section{Spaces of the Jewish Public Library: A Photographic Essay}

What new insights can we garner about the Jewish Public Library by analyzing its spatiality through its photo archive? Drawing on theories of Thirdspace and the punctum, this paper explores everyday Jewish life in and around the JPL through four visual case studies. This method exposes the mechanisms of the library as a work-in-progress, bringing to light the everyday negotiating that defines and redefines the institution - both its folks and elite functions - and its users in a changing urban environment.

Que pouvons-nous apprendre de nouveau sur la Bibliothèque publique juive (BPJ) en analysant sa spatialité au moyen de ses archives photographiques? Employant la théorie du troisième lieu et du punctum, l'article explore la vie juive quotidienne et ses liens avec la BPJ à travers quatre études de cas visuelles. Cette méthode expose les mécanismes de la bibliothèque comme œuvre inachevée, illustrant les négociations quotidiennes qui définissent et redéfinissent l'institution, à la fois ses fonctions populations et d'élite, ainsi que ses usagers, dans un environnement urbain en constante évolution. 